\title{
EFFECTS OF CHARCOAL PRODUCTION ON SOIL IN KILN SITES IN IBARAPA AREA, SOUTH WESTERN NIGERIA.
}

OGUNDELE, A. T., ${ }^{1}$ OLADAPO, O. S. ${ }^{1}$ and ${ }^{*}$ AWETO, A.0. ${ }^{2}$

DOI:http://dx.doi.org/10.4314/ejesm.v5i3.12

Received 7th April 2012; accepted 2nd June 2012

\begin{abstract}
In Nigeria, charcoal is a major source of energy, especially among the urban poor. However, the effects of charcoal production on the environment, especially the soil, have not been adequately documented. This study examines the effects of charcoal production in kiln sites on soil properties in the derived savanna zone of Ibarapa region, south-western Nigeria. Soils in ten kiln sites were sampled at depths of $0-10 \mathrm{~cm}$ and $10-20 \mathrm{~cm}$ and their characteristics were compared with those of the corresponding layers of soil in ten adjoining derived savanna sites which were used as the control. Unlike in previous studies reported for West Africa, charcoal production in the kiln sites did not result in a significant reduction in soil organic matter levels, presumably because the humid climate of the derived savanna zone, hindered a substantial rise in soil temperatures during biomass burning. Similarly, there were no significant increases in the levels of exchangeable cations in both soil layers, except for soil exchangeable sodium. There was a rise in kiln site soil $\mathrm{pH}$ and available phosphorus mainly due to the effects of soil heating. Biomass burning in the kiln sites did not result in significant increases in the levels of the soil micronutrients - extractable iron, copper, zinc and manganese in both the $0-10 \mathrm{~cm}$ and $10-20 \mathrm{~cm}$ soil layers and it had no severe deleterious effects on soil chemical status.
\end{abstract}

Key words: Charcoal production, kiln sites, macronutrients, micronutrients, Nigeria.

\section{Introduction}

Biomass energy, especially fuelwood and charcoal, are the most important sources of energy in developing countries (Aweto, 1995; Arms, 2008; Ghilardi et al., 2009). Even in urban areas where the use of modern fuels such as electricity and liquefied natural gas is becoming increasingly important, the use of traditional fuels, especially fuelwood and charcoal, remains popular among the lowincome earners, on account of the nonaffordability of modern fuels, electric and gas cookers. While the use of fuelwood is predominant in rural areas, charcoal utilization assumes considerable importance among lowincome earners in urban centres. Even in those developing countries that enjoy relatively high income levels, such as Botswana in southern Africa, the use of biomass energy is popular among the poor in rural areas and in towns (Toteng 1998).

The application of charcoal, which is also referred to as biochar, to the soil has several beneficial effects. It has been reported to

${ }^{I}$ Emmanuel Alayande College of Education, Oyo, Lanlate Campus, Lanlate, Oyo State, Nigeria.

${ }^{2}$ Department of Geography, University of Ibadan, Ibadan, Nigeria.

*Corresponding author: albaweto@yahoo.com improve soil fertility and soil biota, and hence, soil biological dynamics (Jin 2010; Lehmann et al, 2011) and to remediate contaminated soils, especially, those containing excessively high levels of heavy metals (Uchimiya et al; 2011). However, the production of charcoal has several adverse environmental effects. It has been linked with deforestation in Brazil and in other parts of the tropics (Kohlhemp, 1995; Naughton-Treves et al, 2007) and with soil deterioration and organic matter decline (Foley 1985; Fontodji et al, 2009). The process of charcoal production also influences soil properties, especially in kiln sites, where dried felled trees are accumulated and burned. In West Africa, which is heavily dependent on biomass energy (Aweto, 1995), the effects of charcoal production on soil properties in kiln sites have not been adequately studied. In Ghana, Oguntunde et al (2004; 2008) and Ayodele et al (2009) examined the effects of charcoal production on soil physical and chemical properties in the derived savanna zone of Ghana, while Fontodji et al (2009) 
carried out a similar study in Togo. There appears to be no comparable studies in Nigeria where fuelwood and charcoal are major sources of energy for cooking, even in urban areas. In fact, a study by Adelekan and Jerome (2006) has shown that owing to government withdrawal of subsidy of petroleum products, more urban residents have switched to the use of traditional fuels such as charcoal and fuelwood, due to the rising cost of kerosene. The heightened and growing demand for charcoal in Nigerian urban centres, consequent upon the withdrawal of the petroleum subsidy by government and bourgeoning urban population, fueled by rural- urban migration, underscore the need to examine the effects of charcoal production on the ecosystem, especially the soil. This is particularly so as the methods of charcoal production vary from place to place (Foley, 1985) and hence, the results of studies carried out in one region may not be directly applicable to another. The studies on the effects of charcoal production on soil in Ghana and Togo referred to above, concentrated on the effects of charcoal production on the topsoil and ignored the subsoil. Furthermore, they did not consider the effects of charcoal production on soil micronutrients. Fontodji et al (2009) studied only one charcoal kiln site for each of the three ecological zones they studied in Togo while Ayodele et al (2009) studied several kiln sites that were cultivated for 2 to 14 months in Ejura, in the derived savanna zone of Ghana, prior to soil sampling. Cultivation of the kiln sites studied by Ayodele et al (2009) may have obliterated or exacerbated the effects of charcoal production in the kiln sites on the soil. The current study, therefore, focuses on the effects of charcoal production on the soil in Ibarapa area of south-western Nigeria where charcoal is produced on a commercial basis for the urban market of Ibadan city. It concentrates on kiln sites which were not cultivated and examines the responses of both the topsoil and subsoil to the process of charcoal production. Since, the previous studies in the West African sub-region did not consider soil micronutrients, it was considered important to include them in the current study.

\section{Study Area}

The current study was conducted in Lanlate area of Ibarapa region of southwestern Nigeria (Figure 1). The area is a part of the high plains of southwestern Nigeria and mean land elevation varies between 100 and 150 metres above mean sea level. It is an undulating plain dissected by numerous rivers, with hills and inselbergs rising above the general land surface. Annual rainfall usually varies between 1400 and $1800 \mathrm{~mm}$ and most of the rains are concentrated in the wet season, lasting from April to about November. The mean annual temperature is $28^{\circ} \mathrm{C}$ with an annual range of $6^{\circ} \mathrm{C}$. The natural vegetation was originally rain forest but it has been transformed into derived savanna as a result of several centuries of farming involving bush burning. Today, key elements of flora are savanna trees such as Parkia biglobosa, Piliostigma reticulata and Vitellaria paradoxa. The main grasses include Panicum maximum, Imperata cylindrica and Andropogon tectorum. The soils are alfisols according to US Soil Taxanomy (Soil Survey Staff 1996) and they are characterized by clayenriched subsoils. 


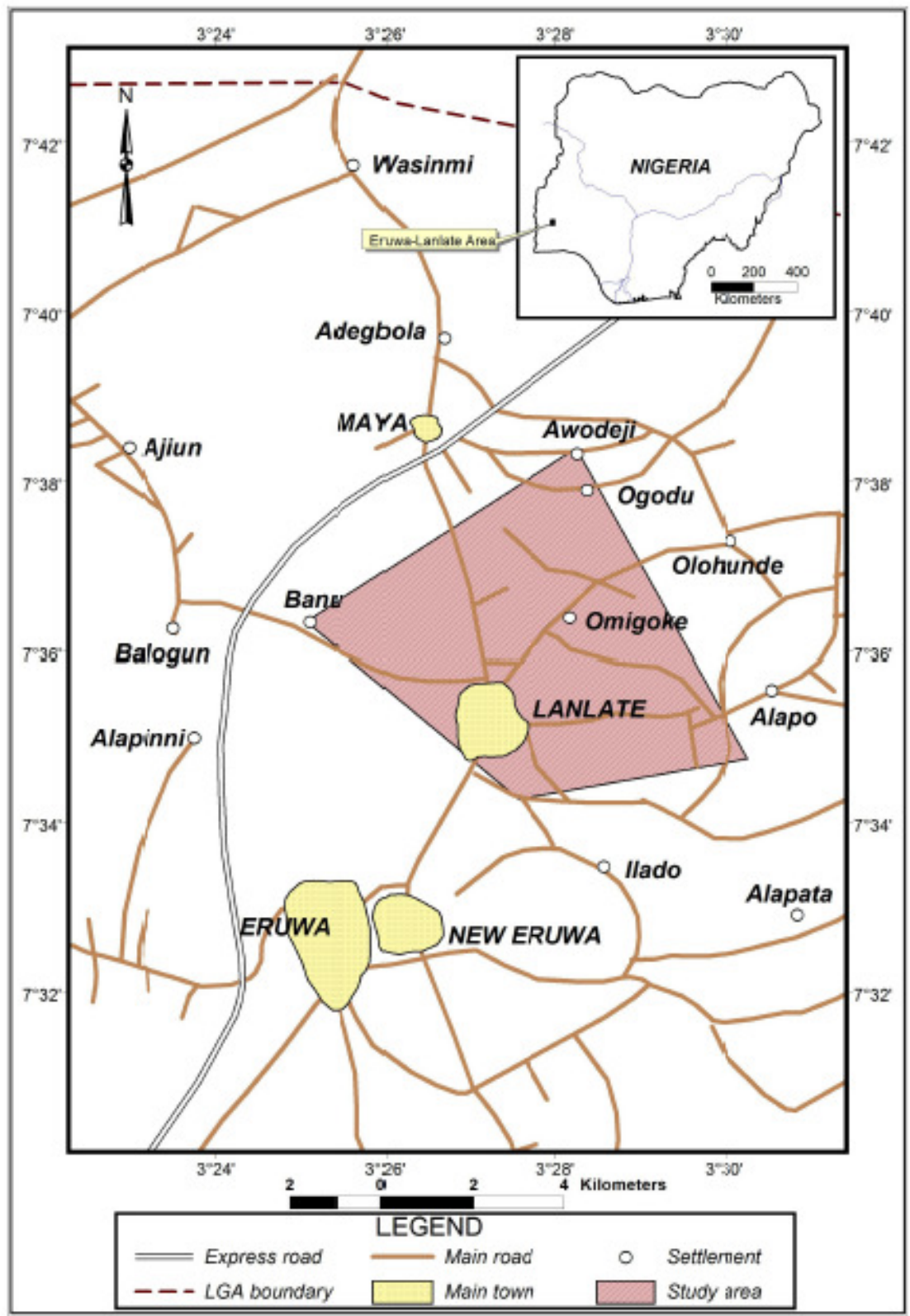

Figure 1: Map of Eruwa - Lanlate area of Ibarapa region, SW Nigeria, showing location of the study area.

\section{Methodology}

The current study seeks to evaluate the effects of charcoal production on the soil in kiln sites where felled trees are converted into charcoal by burning under poorly aerated conditions. It was therefore considered appropriate to compare the characteristics of soils in kiln sites with adjoining soil in order to infer the effects of charcoal production on the soil. For the purpose of soil sampling, quadrats of 5 metres by 5 metres were delimited in ten kiln sites that were selected for study, after a reconnaissance survey of kiln sites in Lanlate area in Ibarapa region of Oyo State in south western Nigeria. Three metres away from each kiln site, another plot of the same dimension was delimited in derived savanna vegetation, where trees were not felled for charcoal production. This was after it was ascertained that the vegetation in the latter site was not 
scorched by fire in the kiln sites. The soil in the latter sample plots served as the control for evaluating the effects of charcoal production on the soil in the kiln sites. The choice of the size of sample plots from which soil samples were collected, was informed by the size of the kiln sites which rarely exceeded the dimension of 5 metres by 5 metres. Within each plot, the soil was sampled at two depths of $0-10 \mathrm{~cm}$ and $10-20 \mathrm{~cm}$ at five randomly selected points. In each kiln site, however, the ash left on top of the soil as a result of burning dried wood to produce charcoal, was scraped off to expose the soil below, prior to soil sample collection. This approach was adopted because the ash is the residue of wood burning that has not been integrated into the soil and as such, cannot be regarded as part of the soil. In order to ensure comparability between the kiln and savanna control sites, they were located on similar position on the catena on flat or gently sloping crestal interfluves in an area characterized by a uniform lithology of quartzite.

The soil samples collected from each of the ten kiln sites and ten adjoining control plots were air- dried, passed through a $2 \mathrm{~mm}$ sieve and analyzed for soil particle size composition using the hydrometer method (Bouyoucos 1962), organic matter using the chromic acid digestion method of Walkley and Black (1934), and total nitrogen by the Kjeldahl method. Soil extracts that were used for determining soil exchangeable cations were obtained by leaching the soil with $1 \mathrm{M}$ ammonium acetate. Exchangeable calcium, potassium and sodium were determined using a flame photometer and exchangeable magnesium by atomic absorption spectrophotometry. Cation exchange capacity was determined as the sum of exchangeable cations and exchange acidity (Sumner and Miller 1996). Soil pH was determined potentiometrically in 0.01 calcium chloride solution (Thomas 1996) while available phosphorus was determined using the method of Bray \& Kurtz (1945).

\section{Data Analysis}

Since an inferential approach, which involved comparing the properties of soil in kiln sites with soil in adjacent savanna was adopted in the current study, it becomes necessary to ascertain whether the soils in both the kiln sites and the adjacent savanna control plots are similar. The application of the students' t-test to compare the proportion of sand, silt and clay in both kiln and savanna control sites revealed that there were no significant differences between them at the 0.01 confidence level. The t-test was also used to compare other physical and chemical properties of soils in kiln and control sites in order to determine whether significant differences exist between them.

\section{Results}

In both the $0-10 \mathrm{~cm}$ and $10-20 \mathrm{~cm}$ layers, the soils in kiln and savanna control sites were texturally similar, being predominantly sandy in both layers (Tables 1 and 2). In respect of textural composition, the soils are loamy sands in both layers. The textural similarity of the soils in both the kiln and savanna control sites implies that the soils in the kiln and savanna control sites are pedogenetically similar. Hence, any observed differences between them with respect to soil chemical status would be most likely due to the effects of charcoal production in the kiln sites.

There were no significant differences between the soils in the kiln and savanna control sites with respect to the organic matter $(P=0.30)$ and total nitrogen status $(P=0.38)$ of the $0-10 \mathrm{~cm}$ layer. Similarly, with the exception of exchangeable sodium, there were no significant differences between soils in kiln and savanna control sites with respect to soil exchangeable nutrient cations. Similar results were obtained for the immediate subsoil layer of $10-20 \mathrm{~cm}$ where the levels of organic matter, total nitrogen and exchangeable cations, excepting sodium, were similar for both the kiln and control sites. However, the levels of soil exchangeable calcium were slightly higher in the kiln sites than in the control sites for both soil layers. The available phosphorus and $\mathrm{pH}$ levels were significantly higher in the $0-10 \mathrm{~cm}$ layer of soil in kiln sites than in savanna control plots at the 0.01 level of the t- distribution. In the $10-20 \mathrm{~cm}$ layer, the differences between soil in kiln and control sites with respect to available phosphorus and exchangeable sodium were observed to be 
significant at the 0.05 level. In both the $0-10$ $\mathrm{cm}$ and $10-20 \mathrm{~cm}$ layers, there were no significant differences between soils in kiln and derived savanna control sites with respect to the concentrations of the micro-nutrients, extractable iron, copper, zinc and manganese. The P-values for the extractable iron, copper, zinc and manganese of the $0-10 \mathrm{~cm}$ soil layer are $0.45,0.40,0.37$ and 0.25 respectively. The corresponding P-values for the four micronutrients listed above for the $10-20 \mathrm{~cm}$ layer are $0.09,0.35,0.20$ and 0.10 respectively.

\section{Discussion}

The production of charcoal in the kiln sites did not result in a significant reduction in the organic matter and total nitrogen levels of both the $0-10 \mathrm{~cm}$ and $10-20 \mathrm{~cm}$ soil layers. In this regard, our results differ from those obtained by Fontodji et al (2009) who reported that charcoal production resulted in considerable reduction in soil organic matter in kiln sites compared to control sites. Bird et al (2000) also reported that savanna burning in Matopos, south western Zimbabwe, resulted in a decline in the organic matter level in the $0-5 \mathrm{~cm}$ soil layer relative to the levels in plots that were not burnt. It is significant to observe that the intensity of soil heating, due to burning biomass directly on the soil or in earth kilns for charcoal production, varies considerably regionally, depending on the climate. Andriesse and Schelhaas (1987) observed that the temperature attained by the soil as a result of biomass burning, was considerably higher in the drier monsoon forest of Thailand than in the wet equatorial region of Sarawak in Malaysia. It would seem that the soil temperatures are not sufficiently high in the earth kilns used for charcoal production in the study area, where the climate is humid rainforest climate, on account of which soil organic matter was not thermally decomposed. Fontodji et al (2009) studied the effects of charcoal production in three ecological zones including Sudan and Guinea savanna zones, which are considerably drier than the derived savanna zone, in which the current study was carried out.

Table 1: The properties of the $0-10 \mathrm{~cm}$ layer (topsoil) of the kiln sites that were used for charcoal production and the adjoining derived savanna control sites.

\begin{tabular}{|l|l|l|l|}
\hline Soil properties & $\begin{array}{l}\text { Kiln sites } \\
\mathrm{n}=10\end{array}$ & $\begin{array}{l}\text { Control sites } \\
\mathrm{n}=10\end{array}$ & t- value \\
\hline Sand $(\%)$ & $83.8 \pm 1.67$ & $84.8 \pm 1.48$ & 0.45 \\
\hline Silt $(\%)$ & $7.6 \pm 1.01$ & $7.2 \pm 0.87$ & 0.43 \\
\hline Clay $(\%)$ & $8.6 \pm 1.29$ & $8.0 \pm 0.88$ & 0.31 \\
\hline Organic carbon $(\%)$ & $1.58 \pm 0.17$ & $1.46 \pm 0.13$ & 0.57 \\
\hline Total nitrogen $(\%)$ & $0.35 \pm 0.04$ & $0.34 \pm 0.03$ & 0.30 \\
\hline Exchangeable calcium $(\mathrm{cmol} / \mathrm{kg})$ & $1.32 \pm 0.02$ & $1.28 \pm 0.06$ & 0.69 \\
\hline Exchangeable magnesium $(\mathrm{cmol} / \mathrm{kg})$ & $0.56 \pm 0.02$ & $0.55 \pm 0.01$ & 0.28 \\
\hline Exchangeable potassium $(\mathrm{cmol} / \mathrm{kg})$ & $0.13 \pm 0.01$ & $0.13 \pm 0.01$ & 0.00 \\
\hline Exchangeable sodium $(\mathrm{cmol} / \mathrm{kg})$ & $0.16 \pm 0.08$ & $0.08 \pm 0.00$ & $2.23^{*}$ \\
\hline Cation exchange capacity $(\mathrm{cmol} / \mathrm{kg})$ & $2.32 \pm 0.04$ & $2.37 \pm 0.09$ & 0.57 \\
\hline Available phosphorus $(\mathrm{mg} / \mathrm{kg})$ & $11.2 \pm 2.45$ & $2.1 \pm 0.18$ & $3.71^{* *}$ \\
\hline Extractable iron $(\mathrm{mg} / \mathrm{kg})$ & $82.6 \pm 2.97$ & $83.4 \pm 2.07$ & 0.22 \\
\hline Extractable manganese $(\mathrm{mg} / \mathrm{kg})$ & $123.1 \pm 4.19$ & $119.7 \pm 3.19$ & 0.65 \\
\hline Extractable copper $(\mathrm{mg} / \mathrm{kg})$ & $7.2 \pm 0.24$ & $7.4 \pm 0.16$ & 0.29 \\
\hline Extractable zinc $(\mathrm{mg} / \mathrm{kg})$ & $15.7 \pm 1.29$ & $16.3 \pm 1.19$ & 0.34 \\
\hline $\mathrm{pH}$ & $5.7 \pm 0.18$ & $4.8 \pm 0.16$ & $3.73^{* *}$ \\
\hline
\end{tabular}

Figures, except t- values, are means \pm standard errors.

* Differences between means are significant at 5\% confidence level.

** Differences between means are significant at $1 \%$ level. 
Table 2: The properties of the $10-20 \mathrm{~cm}$ layer of soil in kiln sites used for charcoal production and the adjoining derived savanna control sites.

\begin{tabular}{|l|l|l|l|}
\hline Soil properties & $\begin{array}{l}\text { Kiln site } \\
\mathrm{n}=10\end{array}$ & $\begin{array}{l}\text { Control sites } \\
\mathrm{n}=10\end{array}$ & t-value \\
\hline Sand $(\%)$ & $85.0 \pm 1.26$ & $85.4 \pm 1.08$ & 0.24 \\
\hline Silt $(\%)$ & $7.6 \pm 0.70$ & $7.2 \pm 0.36$ & 0.51 \\
\hline Clay $(\%)$ & $7.4 \pm 0.87$ & $7.4 \pm 1.03$ & 0.00 \\
\hline Organic carbon $(\%)$ & $0.79 \pm 0.07$ & $0.77 \pm 0.14$ & 0.12 \\
\hline Total nitrogen $(\%)$ & $0.22 \pm 0.02$ & $0.21 \pm 0.03$ & 0.30 \\
\hline Exchangeable calcium $(\mathrm{cmol} / \mathrm{kg})$ & $1.33 \pm 0.06$ & $1.27 \pm 0.07$ & 0.63 \\
\hline Exchangeable magnesium $(\mathrm{cmol} / \mathrm{kg})$ & $0.59 \pm 0.02$ & $0.57 \pm 0.02$ & 0.67 \\
\hline Exchangeable potassium $(\mathrm{cmol} / \mathrm{kg})$ & $0.13 \pm 0.01$ & $0.13 \pm 0.01$ & 0.00 \\
\hline Exchangeable sodium $(\mathrm{cmol} / \mathrm{kg})$ & $0.09 \pm 0.01$ & $0.08 \pm 0.01$ & $2.22^{*}$ \\
\hline Cation exchange capacity $(\mathrm{cmol} / \mathrm{kg})$ & $2.30 \pm 0.10$ & $2.44 \pm 0.09$ & 1.04 \\
\hline Available phosphorus $(\mathrm{mg} / \mathrm{kg})$ & $3.9 \pm 0.80$ & $1.6 \pm 0.14$ & $2.86^{*}$ \\
\hline Extractable iron $(\mathrm{mg} / \mathrm{kg})$ & $83.0 \pm 3.10$ & $88.5 \pm 2.22$ & 1.44 \\
\hline Extractable manganese $(\mathrm{mg} / \mathrm{kg})$ & $130.8 \pm 4.86$ & $120.8 \pm 5.31$ & 1.39 \\
\hline Extractable copper $(\mathrm{mg} / \mathrm{kg})$ & $7.8 \pm 0.24$ & $7.5 \pm 0.31$ & 0.78 \\
\hline Extractable zinc $(\mathrm{mg} / \mathrm{kg})$ & $15.2 \pm 1.87$ & $17.4 \pm 1.39$ & 0.95 \\
\hline pH & $5.0 \pm 0.23$ & $4.5 \pm 0.16$ & 1.60 \\
\hline
\end{tabular}

Figures, except t-values, are means \pm standard errors.

* Differences between means are significant at 5\% confidence level.

Although, biomass burning releases large quantities of ash, rich in exchangeable nutrient cations such as calcium, magnesium, potassium and sodium into the soil, thereby leading to elevated levels of exchangeable cations in the soil as the studies of Oguntunde (2004, 2008) and Fontodji et al (2009) have shown, our study did not reveal any significant enrichment of soil exchangeable cations, excepting sodium, in the kiln sites, relative to soil in the control sites. This is largely because the soils were sampled during the dry season and rain has not fallen since biomass was burnt in the kiln sites. The implication of this was that significant amounts of ash have not been leached downwards into the soil to enhance the levels of nutrients in the soil. Brady and Weil (2002) observed that when ash, which is usually rich in bases is added to the soil, the base cations released into the soil would replace $\mathrm{H}+$ ions in the soil exchange sites, thereby leading to a rise in soil $\mathrm{pH}$. Since, the amount of ash incorporated into the soil as a result of biomass burning in the kiln sites was not considerable, in view of the fact that rain has not fallen to leach ash downwards, one would not therefore, expect a significant rise in the exchangeable cation levels in the soil. Besides, as pointed out in the methodology, the ash on top of the soil was not sampled with the soil. It is important in studies on the effects of charcoal production on soil, to indicate whether or not much rain has fallen since burning vegetation biomass in earth kilns, as this is a crucial factor that would determine whether or not significant amounts of ash would be eluviated downwards to improve the nutrient status of the soil. Furthermore, it is important to indicate whether ash overlying the soil was sampled as part of the topsoil as this would influence soil nutrient status as a result of ash addition to the soil.

The results of the current study indicate a significant increase in the levels of $\mathrm{pH}$, exchangeable sodium and available phosphorus in the $0-10 \mathrm{~cm}$ layer of soil in the kiln sites relative to control sites. The rise in soil $\mathrm{pH}$ levels in the kiln sites is presumably due to the effects of soil heating. Certini (2005) has pointed out that soil $\mathrm{pH}$ is increased as a result of soil heating due to the denaturation of organic acids. Ulery et al 
(1993) have also observed a significant rise in soil $\mathrm{pH}$ levels, following biomass burning and they attributed this to the production of potassium and sodium oxides and hydroxides. The significant increase in the exchangeable sodium level in $0-10 \mathrm{~cm}$ and $10-20 \mathrm{~cm}$ soil layers is presumably indicative of the release of oxides and hydroxides of sodium into the soil, following biomass burning. It is instructive to observe that the savanna soils studied have very low cation exchange capacity, which is usually under $3.0 \mathrm{cmol} \mathrm{kg}{ }^{-1}$, due to their low organic matter content. Given their low CEC and their attendant very low buffering capacity, a slight rise in exchangeable cations is enough to increase soil base saturation, thereby leading to a rise in soil $\mathrm{pH}$. Similarly, the significant increase in the levels of available phosphorous appears to be primarily due to the effects of soil heating as a result of biomass burning rather the effects of ash addition. If the rise in the phosphorus level in soil in the charcoal production sites was due primarily to the effects of ash addition to the soil, there would have been a commensurate significant increase in the levels of soil base cations, especially calcium and magnesium in soil in kiln sites. Soil heating usually results in an increase in soil available phosphorus level and this is particularly marked in shifting cultivation areas where vegetation biomass is burnt prior to cultivation (Giardina et al., 2000; Lawrence and Schlesinger 2001). This effect is primarily due to the killing of soil microorganisms and the enhanced thermal mineralization of soil organic matter and the attendant release of plant-available phosphorous into the soil as a result of fire (Giardina et al., 2000; Arunachalam 2002). Giardina et al (2000) observed that in dry tropical forest with a marked seasonality in rainfall distribution, especially in dry forest on the Pacific coast of Mexico, nitrogen and phosphorus input into the soil as a result of soil heating, is considerably more than ash input of the two nutrients.

The effects of biomass burning to produce charcoal in the kiln sites are not restricted to the overlying $0-10 \mathrm{~cm}$ soil layer. In the $10-20 \mathrm{~cm}$ soil layer, the levels of available phosphorus and sodium were significantly higher in the kiln sites (Table 2). It is not unexpected that charcoal production would impact on the properties of the immediate subsoil as Debano (2000) observed that the effects of soil heating due to biomass burning extends to the depth of $20-30 \mathrm{~cm}$ below the surface.

\section{Conclusion}

Contrary to widespread belief, charcoal production by burning biomass in kiln sites does not always result in the enhancement of soil base nutrient status as a result of ash fertilization. The current study did not observe a significant increase in the levels of exchangeable cations, especially exchangeable calcium, magnesium and potassium, in the soil due to burning of trees in kiln sites for charcoal production, unlike previous studies in West Africa such as those of Oguntunde et al (2004, 2008) and Fontodji et al (2009). In several instances, the amount of ash released in the kiln site is not considerable as aeration is limited so that more tree biomass would be converted into charcoal. In this regard people who produce charcoal from tree biomass differ from shifting cultivators who aim at converting most of the cut slash of vegetation into ash in order to fertilize the soil with a view to giving the crops cultivated after the burn a headstart. The current study also did not observe a decline in soil organic matter and total nitrogen as result of biomass burning in charcoal production sites as reported by Fontodji et al (2009) in the savanna zones of Togo and Oguntunde et al (1984) in Ghana. Also, charcoal production in kiln sites did not significantly affect the levels of the micronutrients zinc, copper, iron and manganese in the $0-10$ and $10-20 \mathrm{~cm}$ soil layers. It would seem that in the rain forest environment, which was subsequently degraded into derived savanna, where the present study was carried out, soil temperatures do not rise considerably in the immediate topsoil layer during biomass burning so as to result in a marked decline in soil organic matter and total nitrogen levels. The findings of the current study and a comparative evaluation of the findings reported in the literature would seem to 
suggest that the effect of charcoal production on the soil varies with ecological and climatic zones and hence with the intensity of heat generated during the burning of vegetation biomass. Variations in the tree flora of vegetation, due to changes in climate and soil conditions, would result in spatial variation in the chemical composition of trees and this, would in turn, influence the chemical composition of ash produced as result of biomass burning. Hence, spatial variations in tree flora of vegetation would ultimately result in varying effects of tree biomass burning on soil chemical composition. Finally, it is important to observe that charcoal production in the study area does not adversely affect soil chemical status, but results in human-mediated spatial heterogeneity of soil, by modifying soil properties in kiln sites.

\section{References}

Adelekan, I. O. and Jerome, A. T. (2006), Dynamics of household energy consumption in a traditional African city, Ibadan. Environmentalist 26, 99-110.

Andriesse, J. P. and Schelhaas, R. M. (1987) A monitoring study on nutrient cycles in soils used for shifting cultivation under various climatic conditions in tropical Asia. III. The effects of land clearing through burning on fertility level. Agriculture, Ecosystems \& Environment 19: 311 - 332.

Arms, K. (2008) Environmental Science. Holt, Rinehart and Winston, Orlando.

Arunachalam, A. (2002) Dynamics of soil nutrients and microbial biomass during first year cropping in an 8-year jhum cycle. Nutreint Cycling in Agroecosystems 64 : 283291.

Aweto, A. O. (1995) A spatio-temporal analysis of fuelwood production in West Africa. OPEC Review 19, 333- 347.

Ayodele, A., Oguntunde, P., Abiodun, J. and Dias Jr., M. S. (2009), Numerical analysis of the impact of charcoal production on soil hydrological behaviour, runoff response and erosion susceptibility. Revista de Ciencia do Solo 33, 137 - 146.

Bird, M. I. Veenendal, E. M., Moyo, C., Lloyd, J. and Frost, P.(2000), Effect of fire and soil texture on soil carbon in a sub-humid savanna (Matopos, Zimbabwe). Geoderma 94, 71-90.

Bouyoucos, G. J. (1962), Hydrometer method improved for making particle size analysis of soils. Agronomy Journal 54, 464-465.

Brady, N.C. and Weil, R.R. (2002) The Nature and Properties of Soils. Prentice Hall, Upper Saddle River, New Jersey.

Bray, P. and Kurtz, L. T. (1945), Determination of total, organic and available forms of phosphorus in soils. Soil Science 59, 39-45.

Certini, G. (2005), Effects of fire on soil properties: a review. Oecologia 143, 1-10.

DeBano, L. F. (2000), The role of fire and soil heating on water repellence in wildland environments: a review. Journal of Hydrology 231, $195-206$.

Foley, G. (1985), Wood fuel and conventional fuel demands in the developing world. Ambio 14, 253-258.

Fontodji, F., Mawussi, G., Nuto, Y. and Kokou, K. (2009) Effects of charcoal production on soil biodiversity and soil physical and chemical properties in Togo. International Journal of Biological and Chemical Sciences 3: 870-879.

Ghilardi, A., Guerrero, G. and Masera, O. (2009), A GIS-based methodology for highlighting fuelwood supply/demand imbalances at the local level: a case study of Central Mexico. Biomass and Bioenergy 33, 957- 972.

Giardina, C.P., Sanford, R.L. and Dockersmith, I.C. (2000) Changes in soil phosphorus and nitrogen during slash-andburn clearing of a dry tropical forest. Soil Science Society of America Journal 64, $339-405$.

Jin, H. (2010) Characterization of microbial life colonizing biochar and biochar-amended soils. Ph.D. thesis, Cornell University, Ithaca, New York.

Kohlhemp (1995) The international pilot programme for Amazonia: An approach to sustainable regional development. International Geographical Union Bulletin 45, 17-30.

Lawrence, D. and Schelesinger, W.H. (2001) Changes in soil phosphorous during 200 years 
of shifting cultivation in Indonesia. Ecology 82: 2769-2780.

Lehmann, J., Rillig, M. C., Thies, J., Masiello, C. A., Hockaday, W.C. and Crowley D. (2011), Biochar effects on biota - A review. Soil Biology \& Biochemistry 43, 1812 $-1836$.

Naughton-Treves, L., Kammen, D. and Chapman, C. (2007), Burning biodiversity: woody biomass use by commercial and subsistence groups in western Uganda's forests. Biological Conservation 134, 232-241. Oguntunde, P.G., Fosu, M., Ajayi, A. E. and van de Giesen, N. (2004), Effects of charcoal production on maize yield, chemical properties and texture of soil. Biology and Fertility of Soils 39, 295-299.

Oguntunde, P.G., Abiodun, B. J., Ajayi, A. E. and van de Giesen, N. (2008), Effects of charcoal production on soil physical properties in Ghana. Journal of Plant Nutrition and Soil Science 171, 591-596.

Soil Survey Staff (1996), Keys to Soil Taxonomy. United States Department of Agriculture and Natural Resources Conservation Service. Washington D.C.

Sumner, M.E. and Miller, W. P. (1996), "Cation exchange capacity and exchange coefficients", In: Sparks, D. L. (ed.) Methods of Soil Analysis, Part 3 - Chemical Methods.
Soil Science Society of America, Madison, pp. 1201-1229.

Thomas, G. W. (1996), "Soil pH and soil acidity", In: Sparks, D. L. (ed.) Methods of Soil Analysis, Part 3 - Chemical Methods. Soil Science Society of America, Madison, pp. 475-490.

Toteng, E. N. (1998), "Depletion of wood resources in Botswana", In: Atlhopheng, J., Molebatsi, G., Toteng, E. \& Totolo, O. (1998)

Environmental Issues in Botswana, Lightbooks, Gaborone, pp. 59 - 78.

Uchimiya, M., Wartelle, L.H., Klasson, K. T., Fortier, C. A. and Lima, I.M. (2011) Influence of pyrolysis temperature on biochar property and function as a heavy metal sorbent in soil. Journal of Agricultural and Food Chemistry 59, 2501- 2510.

Ulery, A. L., Graham, R. C. and Amrhein, C. (1993), Wood-ash composition and soil pH following intense burning. Soil Science 156, $358-364$.

Walkley, A. and Black, I. A. (1934), An examination of the Detjareff method for determining soil organic matter and a proposed modification to the chromic acid titration method. Soil Science 37, 29-38. 